\title{
MOBILE APPLICATION "NEUROGAME" FOR ASSESSMENT THE ATTENTION, FOCUS AND CONCENTRATION
}

\author{
Mario Loleski ${ }^{1}$, Sofija Loleska ${ }^{2}$, Nada Pop-Jordanova ${ }^{3}$ \\ ${ }^{1}$ Ministry for Interior, Republic of Macedonia \\ ${ }^{2}$ DF Labs, Skopje, Republic of Macedonia \\ ${ }^{3}$ Macedonian Academy of Sciences and Art, Skopje, Republic of Macedonia
}

Corresponding author: Nada Pop-Jordanova, Macedonian Academy of Sciences and Arts, Bul. Krste Misirkov 2, Skopje, Republic of Macedonia, e-mail: popjordanova.nadica@gmail.com

\begin{abstract}
Smartphones are ubiquitous, but it is still unknown what physiological functions can be monitored at clinical quality. In medicine their use is cited in many fields (cardiology, pulmology, endocrinology, rheumatology, pediatrics as well as in the field of mental health).

The aim of this paper is to explain how the use of mobile application can help clients to improve the index of their focus, concentration and motor skills. Our original developed application on Android operating system, named "neurogame" is based on an open source platform to enable assessment and therapeutic stimulation, focus and concentration with the ability to monitor the progress of the results obtained in a larger number of participants (normal subjects as well as patients with different disorders) over a period of time.

Whilst nowadays the predominant focus is on the pharmacological treatments, there is a rapidly growing interest in research on alternative options that will offer help in many cases of disorder management in terms of mobile application games.

In order to have some kind of "norms", we evaluated a group of healthy population. Obtained results will serve as a database for comparison the future results. This article displays the results obtained as database.
\end{abstract}

Keywords: Mobile applications, normal population, trigger response

\section{INTRODUCTION}

Mobile phones are largely used today in the form of smart devices supplying a wide range of possibilities in terms of more than just a phone for calls and messages. Even the lower classes of these devices are characterized by hardware performance which has not been even standard in regular computer equipment ten years ago. Reductionin the size of electronic components in current devices allows integration of numerous sensor components. It is no coincidence that modern smart devices start the application in both, scientific and technical research related to different fields such as medicine, biology, physics, etc.

The potential for use of modern mobile devices for medical purposes is huge. In our recent publication [Pop-Jordanova et al., 2017] we evaluated 
the possibilities of mobile phone uses in different fields of medicine using data published in Medline.

The best way to leverage the technical capabilities that today's smart devices offer is through the combined concept of organization of its applicative usage with the methodological approach of undertaking and interpretation of the derivative data from its operations, i.e. from the information that will be supplied to the device. The hardware capabilities of modern smart devices are of great importance. It is not only the powerful processor that they possess, but also the size of the memory space, quality and integration of sensor components (light sensor, motion sensor, GPS receiver, output audio interface, etc.).

The possibility offered by these components can provide basic applicative usage for medicinal purposes (assessment, treatment and monitoring of activities and obtained results) of a large group of respondents and increase efficiency in the statistical calculation of the data.

The development of the software solution requires knowledge not only of the methodology for the development of standard software solutions for mobile applications, but also the use of concepts for data extraction from the activity of the hardware capabilities of the device by using methods based in digital forensics. Using such approach gives us emphasis on the relevance of the data provided by the device and isolating the unwanted possibilities of contamination around the required data. It is of great importance for this kind of research because today's smart devices in which the Android operating system is installed, are largely open to the user and the same allow installation of a large number of software applications and they could potentially make changes to the data of interest [Loleski M. Forensic analysis of Android operating systems, 2013].

On the other hand, using appropriate statistical methods will ensure proper monitoring of the respondents and the success of the applied method for the treatment of different disorders such as some neurological disorders, ADHD, autism or OCD (obsessive compulsive disorder).

A plethora of innovative play therapy techniques additional to the medical treatment have been developed in recent years to implement the therapeutic powers of play.

Additionally, biofeedback-modulated video games are constructed to respond to different physiological signals (skin conductance, hearth rate, temperature, brain waves etc.) rewarding specific healthy body signals by allowing to play a video or mobile game [Pop-Jordanova N.; 2007].

The aim of this research was the development of an original application for Android operating system we named as "neurogame", based on an open source platform for assessment and therapeutic stimulation, as well as monitoring of the results at a larger number of respondents. Firstly, we gathered data for a group of "healthy" subjects (people without any physical or mental problems) aged between 6 and 60 years. This method of assessment provided some form of database which will be used in the future for comparison and monitoring the results for patients with different health problems.

The application is now available to be installed on the client's mobile device, with their prior written consent, and based on their interaction with the device on a daily basis. In other words, this application would demonstrate the effect of the applied method as an additional treatment of the patient. The application enables a direct stimulation of the patient in a so-called Biofeedback working mode, through the use of multimedia capabilities of the device and will provide statistical results related to the interaction of the respondents/patients with the device within a time range of the application treatment.

The application does not relate to the personal data of patients in any way and for safety reasons Internet resources for potential data sharing will not be used. The provision of the derivative data from the application will take place in strictly controlled conditions, on the grounds of the fact that their relevance shall not be questioned. The example of the application in a working mode is shown on Fig.1.

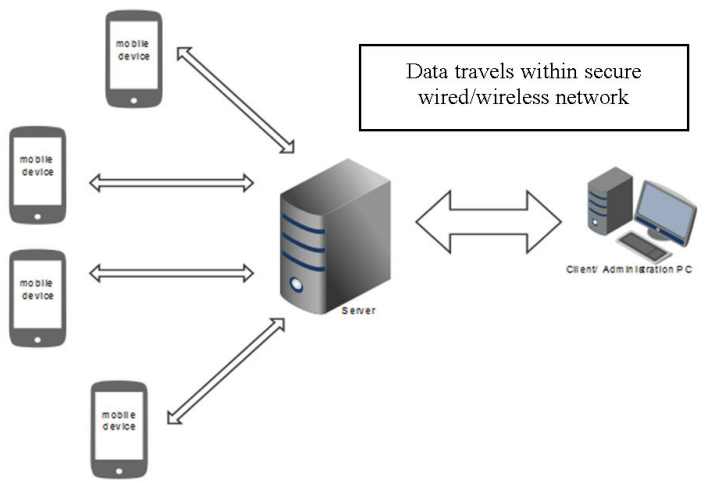

Figure 1. General system organization

Future directions are statistical analysis of the results of this application, and the use of this device for patients manifesting problems with 
motor skills, concentration and social skills. The analysis of obtained results will direct the doctor to determine whether each resident should continue with such a therapy or move to the next level for better performance.

\section{SUBJECTS AND METHODOLOGY}

As we explained previously, the first step of this research was to obtain data for normal clients which will serve as a database for the further evaluation. In this context, we evaluated a group of 201 clients, different age, both genders and different professions. All of them did not have any health problem, neither physical nor mental.

The testing for all clients was performed in the morning period (8-12 am.) with obtained prior consent and explanation about the aim of the study.

The principle of the game we constructed is presented on Fig. 2

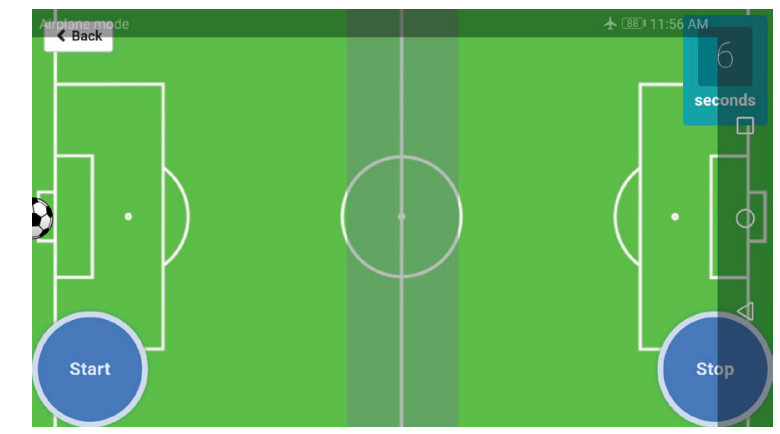

LEFT THUMB

RIGHT THUMB

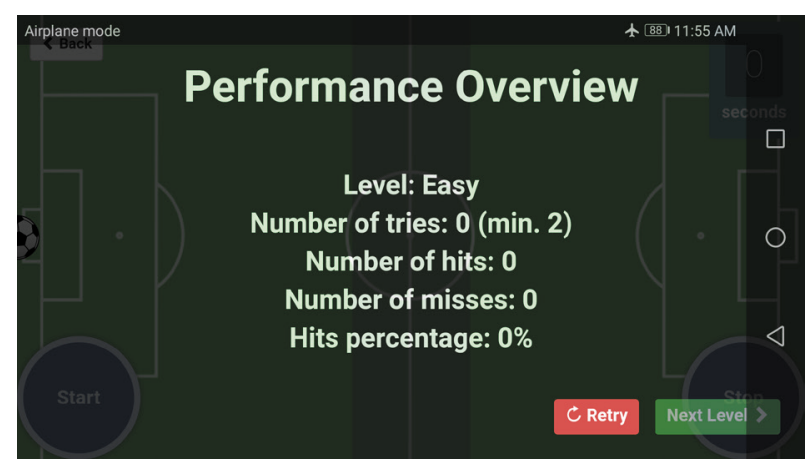

Figure 2. The "neurogame" screens

There are five levels of the game: very easy, easy, normal, hard and very hard related to the speed of the ball movement. The client should stop the ball within the gray area at the center. Every harder level means greater ball speed and less gray area to place the ball. The results are related to fine motor skills and reaction time depending on the attention and concentration level of the client.

Obtained results are presented in tables and graphs. Some statistical analysis (ANOVA, Student t-test) is performed using Statistic package version 8 .

\section{RESULTS FOR "NORMAL" CLIENTS}

Total number of examinees was $201,59 \%$ (119) were males and $41 \%$, (82) were females (Table 1).

Table 1. Gender of the examined clients

\begin{tabular}{|c|c|c|}
\hline Gender & Number & Percent \\
\hline Male & 119 & $59 \%$ \\
\hline Female & 82 & $40,80 \%$ \\
\hline Total & 201 & $100 \%$ \\
\hline
\end{tabular}

Number of examinees, grouped in the following samples: children in Elementary school; students in Universities, Employed (nonprofessional athletes, scientific workers) and others, are displayed in Table 2.

Table 2. Groups of examinees

\begin{tabular}{|l|l|l|}
\hline Occupation & Number & Percentage \\
\hline Elementary school & 119 & $59.20 \%$ \\
\hline Employed & 48 & $23.88 \%$ \\
\hline Student & 31 & $15.42 \%$ \\
\hline Other & 3 & $1.49 \%$ \\
\hline Total & 201 & $100.00 \%$ \\
\hline
\end{tabular}

\section{Occuption overview}

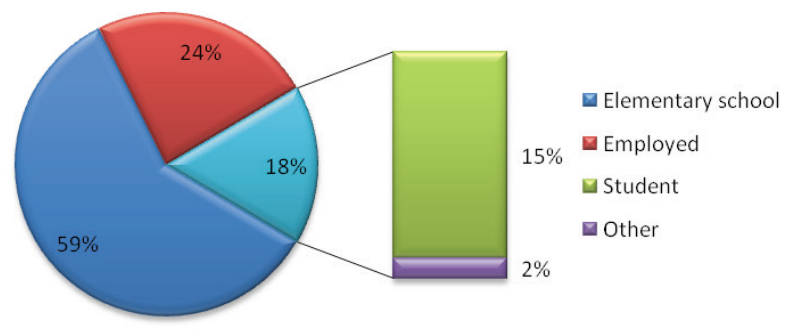

Figure 3. Occupation overview 
In this research we were interested to compare the results obtained for persons whoare active in sport with other non-sportive ones. For this reason we have selected athletes included in different groups: From Elementary school 17 schoolers were Athletes. From Student group 16 students were Athletes. From Employed group 15 people were Athletes and 22 people were full time Athletes. From group other, 2 people were Athletes.

As a result, we have obtained a group of athletes which comprised 70 examinees, as displayed in the below Table 3 .

Table 3. Clarification of groups

\begin{tabular}{|c|c|}
\hline Groups of examinees & Number \\
\hline Athletes & 70 \\
\hline Schoolers & 107 \\
\hline Scientists & 24 \\
\hline Total & 201 \\
\hline
\end{tabular}

Results obtained for different levels of the game for all examinees are presented in Table 4. Reaction time is measured in milliseconds.

Table 4. Results for tries, hits, misses and time (in milliseconds)

\begin{tabular}{|l|l|l|l|l|}
\hline $\begin{array}{l}\text { Level } \\
\text { description }\end{array}$ & $\begin{array}{l}\text { Average } \\
\text { Tries }\end{array}$ & $\begin{array}{l}\text { Average } \\
\text { Hits }\end{array}$ & $\begin{array}{l}\text { Average } \\
\text { Misses }\end{array}$ & $\begin{array}{l}\text { Average } \\
\text { time (ms) }\end{array}$ \\
\hline $\begin{array}{l}\text { Level 0 } \\
\text { (Very easy) }\end{array}$ & 30,88 & 13,27 & 17,61 & 490,9 \\
\hline $\begin{array}{l}\text { Level 1 } \\
\text { (Easy) }\end{array}$ & 34,96 & 11,03 & 23,92 & 368 \\
\hline $\begin{array}{l}\text { Level 2 } \\
\text { (Normal) }\end{array}$ & 37,94 & 10,03 & 27,9 & 284,67 \\
\hline $\begin{array}{l}\text { Level 3 } \\
\text { (Hard) }\end{array}$ & 40,06 & 8,77 & 31,22 & 185,51 \\
\hline $\begin{array}{l}\text { Level 4 } \\
\text { (Very hard) }\end{array}$ & 39,47 & 5,37 & 34,09 & 98,91 \\
\hline
\end{tabular}

Table 5 shows maximum number of tries, hits, misses and time for different level of the game, while Table 6 presents minimum tries, hits, misses and time for all examinees.

Table 5. Results for maximum tries, hits, misses and time in different levels

\begin{tabular}{|l|l|l|l|l|}
\hline $\begin{array}{l}\text { Level } \\
\text { description }\end{array}$ & $\begin{array}{l}\text { Max } \\
\text { Tries }\end{array}$ & $\begin{array}{l}\text { Max } \\
\text { Hits }\end{array}$ & $\begin{array}{l}\text { Max } \\
\text { Misses }\end{array}$ & $\begin{array}{l}\text { Max } \\
\text { time }\end{array}$ \\
\hline $\begin{array}{l}\text { Level 0 } \\
\text { (Very easy) }\end{array}$ & 81 & 53 & 59 & 584 \\
\hline $\begin{array}{l}\text { Level } 1 \\
\text { (Easy) }\end{array}$ & 83 & 57 & 83 & 459 \\
\hline
\end{tabular}

\begin{tabular}{|l|l|l|l|l|}
\hline $\begin{array}{l}\text { Level 2 } \\
\text { (Normal) }\end{array}$ & 95 & 44 & 60 & 335 \\
\hline $\begin{array}{l}\text { Level 3 } \\
\text { (Hard) }\end{array}$ & 104 & 41 & 71 & 224 \\
\hline $\begin{array}{l}\text { Level 4 } \\
\text { (Very hard) }\end{array}$ & 126 & 57 & 99 & 138 \\
\hline
\end{tabular}

Table 6. Results for minimum tries, hits, misses and time

\begin{tabular}{|c|c|c|c|c|}
\hline $\begin{array}{c}\text { Level } \\
\text { description }\end{array}$ & $\begin{array}{c}\text { Min } \\
\text { Tries }\end{array}$ & Min Hits & $\begin{array}{c}\text { Min } \\
\text { Misses }\end{array}$ & $\begin{array}{c}\text { Min } \\
\text { time }\end{array}$ \\
\hline $\begin{array}{c}\text { Level 0 } \\
\text { (Very easy) }\end{array}$ & 0 & 0 & 0 & 0 \\
\hline $\begin{array}{c}\text { Level 1 } \\
\text { (Easy) }\end{array}$ & 18 & 0 & 2 & 0 \\
\hline $\begin{array}{c}\text { Level 2 } \\
\text { (Normal) }\end{array}$ & 14 & 0 & 9 & 0 \\
\hline $\begin{array}{c}\text { Level 3 } \\
\text { (Hard) }\end{array}$ & 0 & 0 & 0 & 0 \\
\hline $\begin{array}{c}\text { Level 4 } \\
\text { (Very hard) }\end{array}$ & 0 & 0 & 0 & 0 \\
\hline
\end{tabular}

Summarized graphs for reaction time in the group of Schoolers is presented on Fig.4; for athletes on Fig. 5 and for scientists on Fig. 6.

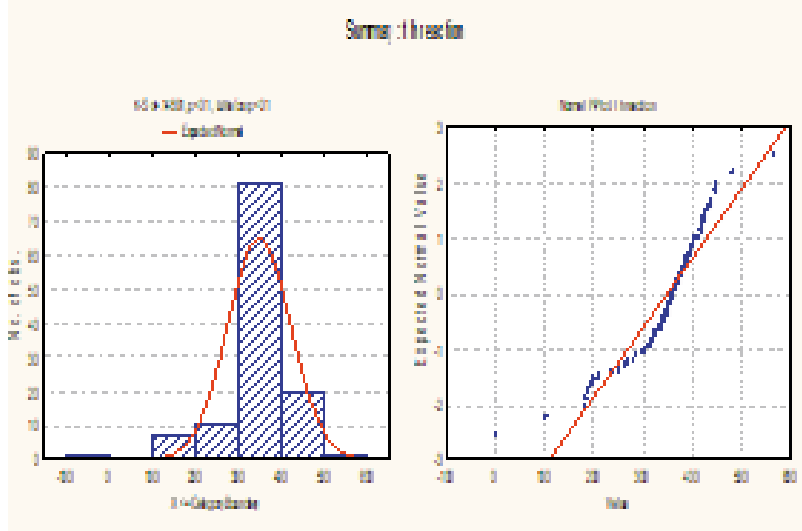

Figure 4. Reaction time for schoolers

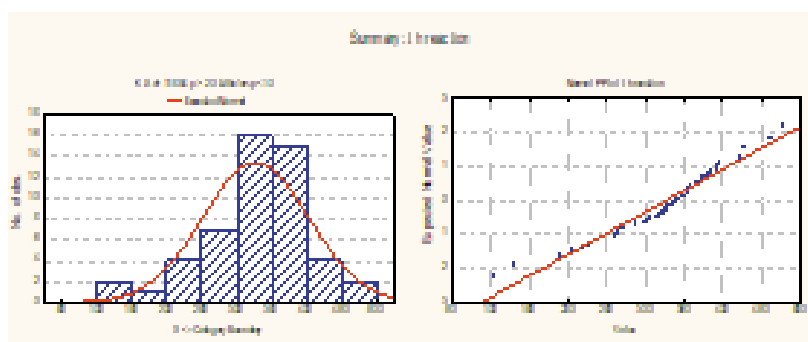

Figure 5. Reaction time for athletes 


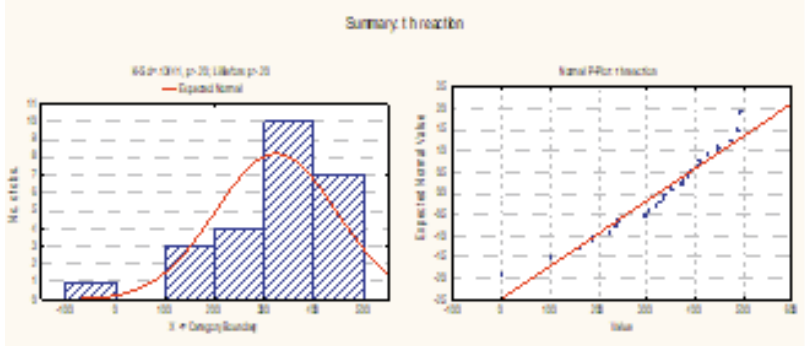

Figure 6. Reaction time for scientists

One-way ANOVA for reaction time in different age in all examinees showed highly significant value (Fig.7).

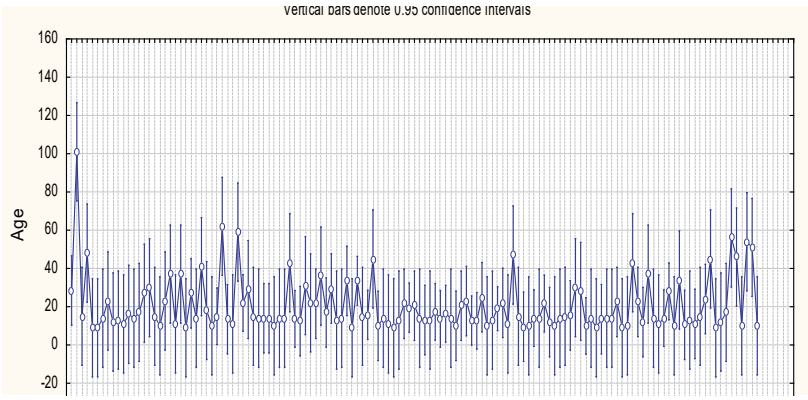

Figure 7. ANOVA reaction time/age

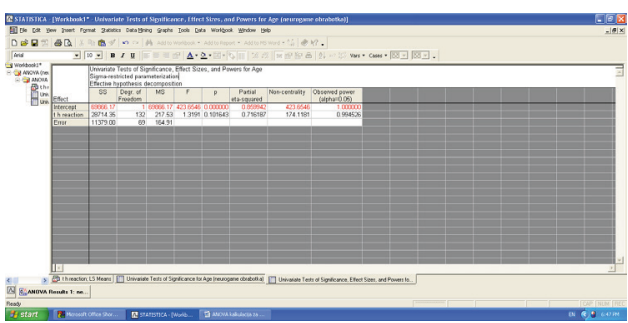

Additionally, the following Fig.8 shows one-way ANOVA for reaction time and gender, which happened to be depicted as not significant.

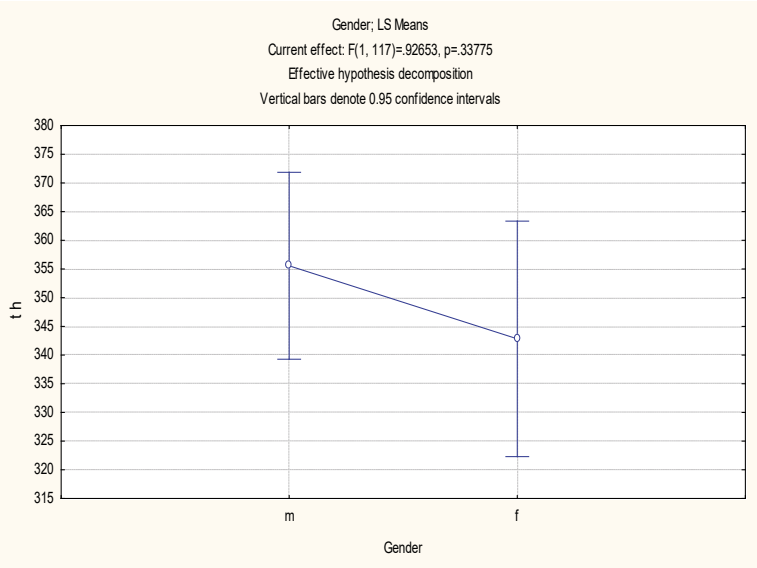

Figure 8. Time reaction in both gender
Calculated Student t-test by variables between the groups of scholars and athletes for reaction time is presented in Table 7 .

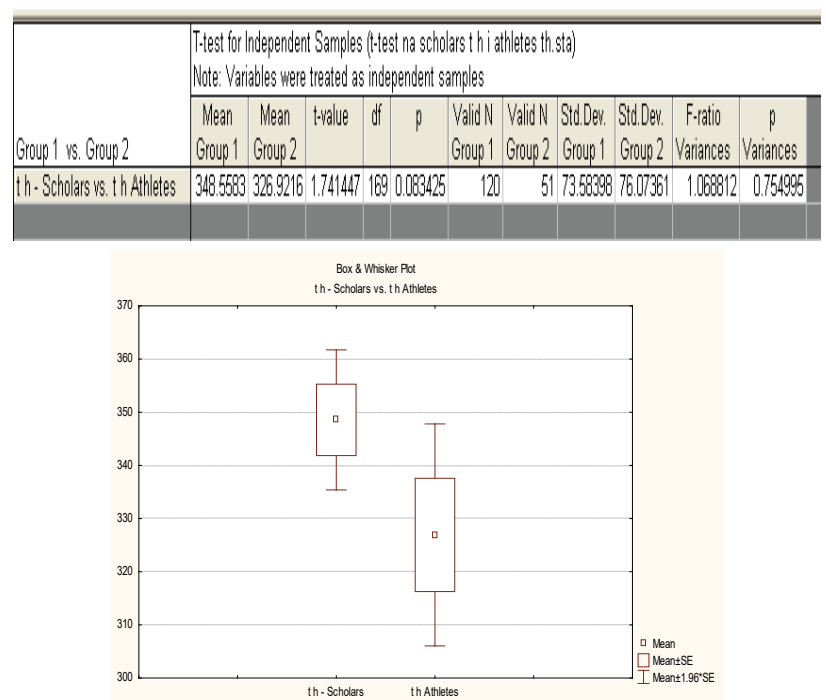

Calculated T-test by variables between the groups of scholars and scientists for reaction time is displayed in Table 8.

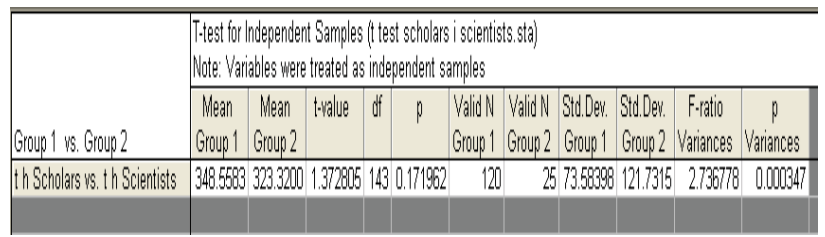

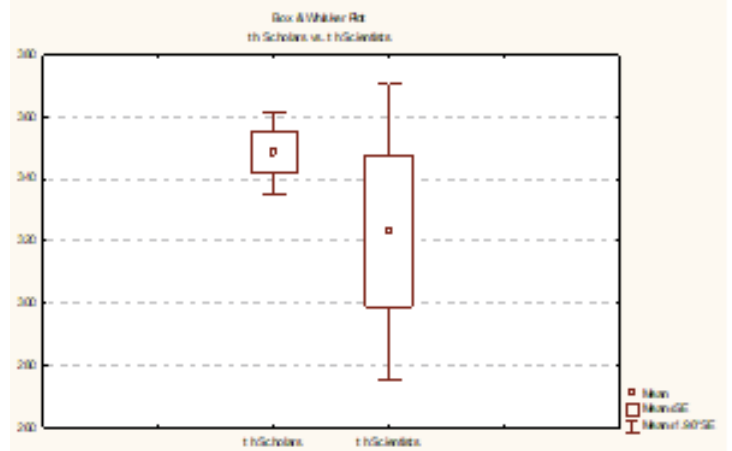

Finally, calculated t-test for reaction time between the group of scientists and athletes is given in Table 9.

Table 9. T-test for reaction time between scientists and athletes

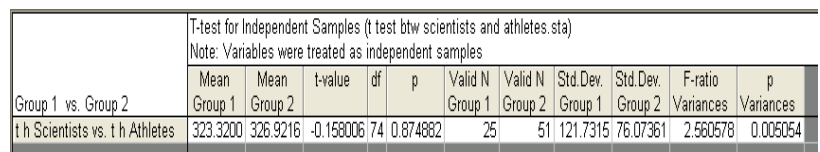




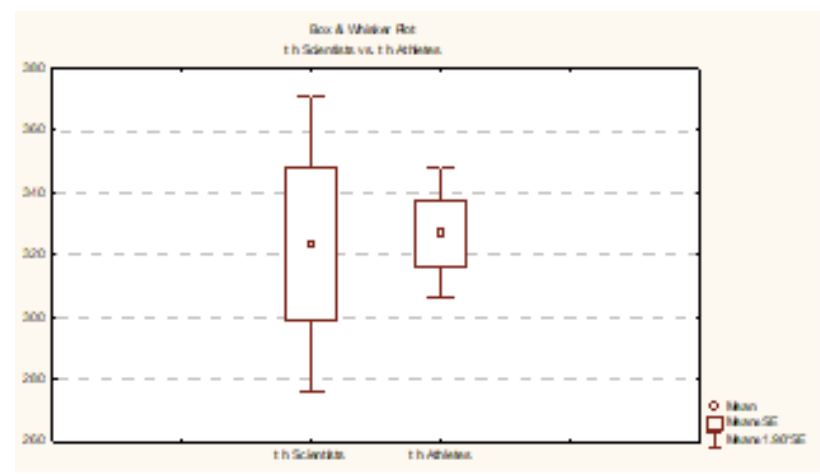

DISCUSSION

As we mentioned before, the use of mobile phones in medicine nowadays is enormous. [Berrouiguet S. et al, 2016]. For example, mobile phones, due to their audio processing capabilities, have the potential to facilitate the diagnosis of heart disease through automated auscultation [Dang S. et all; 2017]. Additionally, smart phone-based electrocardiographic and cardiac implantable electronic device monitoring was used by Mittal S. (2017) and showed that this technique allows the patient to assume a greater stake in their own care.

Cheng Q. et all; (2017) has shown that phone sensors can measure walking patterns of people. They demonstrated that improved classification models can accurately measure pulmonary function, with sole inputs being sensor data from carried phones.

Peacock E. and Krousel-Wood M.(2017) highlighted promising strategies to improve antihypertensive medication adherence and blood pressure control which include regimen simplification, reduction of out-of-pocket costs, use of allied health professionals for intervention delivery, and self-monitoring of blood pressure by technology-mediated interventions, especially by use of mobile phones.

In a study of Richardson JE. et all. (2017), the aim was to determine the role that smart phones may play in supporting older adults with chronic non-cancer pain in order to improve pain management in this expanding population.

In a recent preliminary study of Tay I. et all; (2017) acceptable use of Calci-app to self-monitor calcium consumption has been demonstrated.

Hung S. et all. (2016) published the results of a smart phone application, iHOPE, used to perform a daily ecological momentary assessment of depression, anxiety, sleep and cognitive performance. The study provides initial evidence for the feasibility of smart phone-based ecological momentary assessment in Chinese patients with depression. Similarly, Radovic et al. (2016) published data for the possible use of mobile application in mental health.

Deficits in motor movement automaticity in Parkinson's disease, especially during multitasking, are early and consistent hallmarks of cognitive function decline, which increases fall risk and reduces quality of life. The study of Chomiak T. et all. (2017) tested the feasibility and potential efficacy of a wearable sensor-enabled technological platform designed for an in-home music-contingent stepping-in-place (SIP) training program to improve step automaticity during dual-tasking (DT). Wearable device technology can be used to enable musically-contingent SIP training to increase motor automaticity for people with Parkinson's disease. The training approach described in the mentioned study can be implemented at home to meet the growing demand for self-management of symptoms by the patients.

Triantafyllidis AK. et all. (2016) proposed a framework for designing sensor-based health monitoring systems aiming to provide extensible and usable monitoring services in the scope of pervasive patient care. Portable or wearable sensing devices measure the patient's physiological parameters, a smart mobile device collects and analyses the sensor data, a medical center system receives notifications on the detected health condition, and a health professional platform is used by formal caregivers in order to review the patient condition and configure monitoring schemes.

Recently, Haghi M. et all. (2017) has published a scientific research on current commercially available devices.

In this context, our original Android application named "neurogame" has a similar aim: assessment and training of reaction time for people related to the level of concentration and attention. The first step of our research was to obtain data for healthy people.

As we expected, the results obtained have shown that healthy people similarly performed all tasks. We have shown that reaction time is strongly dependent on the age (ANOVA was highly significant). It means that younger peo- 
ple are faster in reaction and more effective at all levels of the game.

Reaction time is similar for both genders, as well as for different occupations. The active exercise in different sport do not influence the reaction time, which is an astonishing finding. (ANOVA and Student t-test were non-significant). However, reaction time is directly influenced by the attention and concentration as important psychological functions.

All obtained results will serve as a normative base in order to compate results, which will be obtained in the future research for different neurological or mental disorders. We have just started the evaluation for neurological disorders (post ictus patients, Parkinsonian and epileptic ones). Children with ADHD, OCD or autism will be also evaluated. The same application will be used as an additional non-medical tool for training.

\section{CONCLUSION}

Our model of the application is used for testing the reaction time in healthy people. Reaction time is related to the level of attention and concentration as two very important psychological functions.

We have shown that reaction time is strongly dependent on the age; no significant differences for both genders and types of profession have been noticed.

Surprisingly, no sport activity has any influence onthe reaction time. In other words, sportive activities do not influence the reaction time.

This study confirms the availability and practical values of Android applications in testing the attention and concentration measured by the reaction time in people.

\section{REFERENCES}

1. Pop-Jordanova N, Loleski M, Loleska S. The use of Smartphone in medical practice (Review), Prilozi, Contributions / Macedonian Academy of Sciences and Arts, Section of Biological and Medical Sciences, 2017; No 3 (in press)

2. Loleski M. Forensic analysis of Android operating systems, MSc thesis, University Goce Delcev, Stip, 2013
3. Pop-Jordanova N. Biofeedback-psychophysiology and applications, Kultura, 2007.

4. Berrouiguet S, Baca-García E, Brandt S, Walter M, Courtet P. Fundamentals for Future Mobile-Health (mHealth): A Systematic Review of Mobile Phone and Web-Based Text Messaging in Mental Health. J Med Internet Res. 2016 Jun 10; 18(6):e135. doi: 10.2196/jmir.5066.

5. Dang S, Karanam C, Gómez-Marín O. Outcomes of a Mobile Phone Intervention for Heart Failure in a Minority County Hospital Population. Telemed J E Health. 2017 Jan 4. doi: 10.1089/ tmj.2016.0211. [Epub ahead of print]

6. Mittal S. Smartphone-Based Electrocardiographic and Cardiac Implantable Electronic Device Monitoring. Cardiol Rev. 2017 Jan/Feb; 25(1):12-16.

7. Cheng Q, Juen J, Bellam S, Fulara N, Close D, Silverstein JC, Schatz B. Classification Models for Pulmonary Function using Motion Analysis from Phone Sensors. AMIA Annu Symp Proc. 2017 Feb 10; 2016:401-410. eCollection 2016.

8. Peacock E, Krousel-Wood M. Adherence to Antihypertensive Therapy. Med Clin North Am. 2017 Jan; 101(1):229-245. doi: 10.1016/j.mcna.2016.08.005.

9. Richardson JE, Lee JI, Nirenberg A, Reid MC. The Potential Role for Smartphones Among Older Adults with Chronic Noncancer Pain: A Qualitative Study. Pain Med. 2017 Jan 20. pii: pnw284. doi: $10.1093 / \mathrm{pm} / \mathrm{pnw} 284$. [Epub ahead of print]

10. Tay I, Garland S, Gorelik A, Wark JD. Development and Testing of a Mobile Phone App for Self-Monitoring of Calcium Intake in Young Women. JMIR Mhealth Uhealth. 2017 Mar 7; 5(3):e27. doi: 10.2196/mhealth.5717.

11. Hung S, Li MS, Chen YL, Chiang JH, Chen YY, Hung GC. Smartphone-based ecological momentary assessment for Chinese patients with depression: An exploratory study in Taiwan. Asian J Psychiatr. 2016 Oct;23:131-136. doi: 10.1016/j. ajp.2016.08.003. Epub 2016 Aug 8.

12. Radovic A, Vona PL, Santostefano AM, Ciaravino S, Miller E, Stein BD. Smartphone Applications for Mental Health. Cyberpsychol Behav Soc Netw. 2016 Jul;19(7):465-70. doi: 10.1089/ cyber.2015.0619.

13. Chomiak T, Watts A, Meyer N, Pereira FV, Hu B. A training approach to improve stepping automaticity while dual-tasking in Parkinson's disease: A prospective pilot study. Medicine (Baltimore). 2017 Feb; 96(5):e5934. doi: 10.1097/ MD.0000000000005934.

14. Triantafyllidis AK, Koutkias VG, Chouvarda I, Adami I, Kouroubali A, Maglaveras N. Framework of sensor-based monitoring for pervasive patient care. Healthc Technol Lett. 2016 Aug 12; 3(3):153-158. eCollection 2016. 
15. Haghi M, Thurow K, Stoll R. Wearable Devices in Medical Internet of Things: Scientific Research and Commercially Available Devices. Healthc Inform Res. 2017 Jan;23(1):4-15. doi: 10.4258/ hir.2017.23.1.4. Epub 2017 Jan 31.

\title{
Резиме
}

\section{РАЗВОЈ НА МОБИЛНА АПЛИКАЦИЈА ЗА ПРОЦЕНКА И ТРЕТМАН}

\author{
Марио Лолески ${ }^{1}$, Софија Лолеска ${ }^{2}$, Нада Поп-Јорданова ${ }^{3}$ \\ ${ }^{1}$ Министерство за внатрешни работи на Република Македонија \\ 2 ДФЛабс, Скопје, Република Македонија \\ ${ }^{3}$ Македонска академија на науките и уметностите, Република Македонија
}

Паметните телефони се широко распространети, но сѐ уште е непознато кои физиолошки функции можат да бидат мониторирани со нив, а да имаат клинички квалитет. Во медицината нивната употреба е цитирана во многу полиња (кардиологија, пулмологија, ендокринологија, ревматологија, педијатрија, како и во полето на менталното здравје).

Целта на овој труд е објаснување како користењето на мобилната апликација може да помогне во подобрувањето на индексот на фокусот на вниманието, концентрацијата и моторните вештини кај корисникот. Нашиот оригинален апликативен систем на Андроид, кој го нарековме „невроигра“, е базиран на платформата „отворен извор“, за да овозможи проценка и терапевтска стимулација, фокусирање и концентрација со можност за мониторирање на напредокот на резултатите кај голема група корисници (нормални субјекти, како и пациенти со разни растројства) во одреден временски период.

Во денешниот предоминантен фокус на фармаколошки третман, постои сѐ поголем интерес во истражувањето на алтернативните можности за менаџирање на многу растројства преку апликации на мобилните телефони во вид на игра.

За да имаме некакви норми, испитавме група на здрава популација. Добиените резултати ќе служат како база на податоци за споредба со идните истражувања. Во овој напис прикажани се резултатите од нормативната база на податоци.

Клучни зборови: мобилна апликација, нормална популација, тригер-одговор 